\title{
THE POTENTIAL OF DIFFERENT FRUIT SPECIES AS FOOD FOR Harmonia axyridis (PALLAS, 1773) (COLEOPTERA: COCCINELLIDAE) ${ }^{1}$
}

\author{
CAMILA FEDIUK DE CASTRO GUEDES² \& LÚCIA MASSUTTI DE ALMEIDA ${ }^{3}$
}

ABSTRACT - Harmonia axyridis was detected for the first time in Brazil in 2002. Since then, it has been recorded from the South to the Midwest of the country. Until now, almost all the registered cases were associated with the presence of aphids, its preferred source of food. Due to the occurrence of this species in areas of fruit growing in the South and Southeast of Brazil, the aim of this study was to analyze the preference and use of three different cultivars of fruit. The tests were set at $25^{\circ} \mathrm{C} \pm 1{ }^{\circ} \mathrm{C}, \mathrm{RH} 70 \% \pm 10 \%$, and in a photophase of $12 \mathrm{~h}$ and with apples (Gala and Fuji), grapes (Niágara and Rubi), and pears (Williams and Asian). In the undamaged fruit experiment, the insects did not cause any noticeable damage. In the damaged and undamaged fruit experiment, a higher and statistically significant percentage of $H$. axyridis adults were found in the three damaged fruits. In the different cultivar experiment the Niágara grape, the Gala apple, and the Williams pear were significantly preferred by $H$. axyridis adults. These results may help in the management of this insect, preventing damage, which have been observed in other places where $H$. axyridis was introduced.

Index terms: Apple, food preference, grape, invasive species, pear.

\section{O POTENCIAL DE DIFERENTES ESPÉCIES DE FRUTAS COMO ALIMENTO PARA Harmonia axyridis (PALLAS, 1773) (COLEOPTERA: COCCINELLIDAE)}

RESUMO - Harmonia axyridis foi detectada pela primeira vez no Brasil em 2002. A partir daí, então tem sido observada do sul ao centro-oeste do País. Até agora, quase todos os casos registrados foram associados com a presença de afídeos, sua principal fonte de alimento. Devido à ocorrência dessa espécie em áreas de cultivo de frutas no Sul e no Sudeste do Brasil, o objetivo deste trabalho foi analisar a preferência e a utilização de três diferentes cultivares de frutas. Os testes foram realizados a $25^{\circ} \mathrm{C} \pm 1{ }^{\circ} \mathrm{C}, \mathrm{UR} 70 \% \pm 10 \%$, e fotofase de 12 h e com maçãs (Gala e Fuji), uvas (Niágara e Rubi), e peras (Williams e Asiática). Nos testes com frutas não danificadas, os insetos não causaram nenhum dano perceptível. Nos testes com frutas danificadas e não danificadas, uma porcentagem maior e estatisticamente significante de adultos de $H$. axyridis foi observada nas três frutas danificadas. Nos testes de preferência, a uva Niágara, a maçã Gala e a pera Williams foram significativamente preferidas pelos adultos de H. axyridis. Esses resultados poderão auxiliar no manejo desse inseto, evitando danos, os quais têm sido observados em outros locais onde H. axyridis foi introduzida.

Termos para indexação: Espécie invasora, maçã, pera, preferência alimentar, uva.

${ }^{1}$ (Trabalho 090-13). Recebido em: 01-03-2013. Aceito para publicação em: 15-10-2013.

${ }^{2}$ Bióloga, MSc., Doutoranda em Entomologia, Universidade Federal do Paraná, Laboratório de Sistemática e Bioecologia de Coleoptera (Insecta), Departamento de Zoologia, Universidade Federal do Paraná - UFPR, Caixa Postal 19030, Curitiba, Brasil. Email: camifc@ yahoo.com.

${ }^{3}$ Bióloga, Prof ${ }^{a}$. Dra. Universidade Federal do Paraná, Laboratório de Sistemática e Bioecologia de Coleoptera (Insecta), Departamento de Zoologia, Universidade Federal do Paraná - UFPR, Caixa Postal 19030, Curitiba, Brasil. Email: almeida51@gmail.com 


\section{INTRODUCTION}

Harmonia axyridis (Pallas, 1773) (Coleoptera: Coccinellidae) is a predator mainly of aphids, and is used as a biological control agent in several crops around the world. Both intentional introductions for biological control and accidental introductions have contributed to its range expansion (HODEK et al., 2012).

Beneficial impacts of $H$. axyridis have been observed in several places. In North America, it occurs in various agricultural and natural systems where it may be contributing to the suppression of pests (COLUNGA-GARCIA; CAGE, 1998; $\mathrm{KOCH}, 2003)$. For example, it has been a successful biological control agent of the pecan aphid complex (TEDDERS; SCHAEFER, 1994). It also seems to be an important predator of Aphis glycines Matsumura, 1917 (Hemiptera, Aphididae), an invasive pest of soybean in North America (MIGNAULT et al., 2006). Nevertheless, as an invasive species, $H$. axyridis may cause negative impacts, including the displacement of natural native enemies and the suppression or extinction of non-target prey species (KOCH, 2003). In the United States, this species was observed competing with other Coccinellidae as Coleomegilla maculata DeGeer, 1775, an important native predator that feeds on many aphid species, as well as other arthropods and insect eggs (HODEK et al., 2012). In Brazil, H. axyridis have been monitored in fields and may compete with Cycloneda sanguinea (Linnaeus, 1763), the main aphidophagous native species (MARTINS et al., 2009).

Coccinellid predators may occasionally feed on pollen and nectar, which makes their survival possible when prey is not available. Consumption of pollen and nectar may increase the volume of reserves for the winter and improve their fitness, even when the preferred food is available (HODEK et al., 2012); this is also the case with $H$. axyridis (LAMANA; MILLER, 1998).

The frugivory in coccinellid predators seems to be rare, but it has been documented for Coccinella septempunctata Linnaeus, 1758 and Adalia bipunctata (Linnaeus, 1758) (HODEK et al., 2012); however, coccinellid predators were never considered a problem for agriculture of economic importance (GALVAN et al., 2008).

Harmonia axyridis has been observed feeding on fruits such as apples, grapes, peaches, plums, pears, pumpkins, and raspberries in North America (KOCH et al., 2004; KOVACH, 2004). In the Eastern United States, wine producers reported that there was a change in the taste and smell of wine, which coincided with a large amount of $H$. axyridis present in the grape clusters. This occurred because the insects were processed along with the fruits for wine production. Toxic alkaloids and bitter tasting substances have been described in the literature as the defense mechanism in Coccinellidae (GALVAN et al., 2009).

Harmonia axyridis was detected in Brazil for the first time in Curitiba, Paraná, in 2002, probably introduced accidentally (ALMEIDA; SILVA, 2002), and since then, there have been records ranging from the South to the Midwest of the country. Until now, almost all reported cases in Brazil were associated with the presence of aphids and its preferred food (MARTINS et al., 2009). However, there is still a lack of knowledge about its behavior and potential use as alternative sources of food, such as fruits, when prey is scarce.

Some of the regions of occurrence of this Coccinellidae species in Brazil are important areas of different fruit cultivar production, such as pears, in the South and Minas Gerais; apples, especially in Santa Catarina; and grapes, mainly in Rio Grande do Sul and São Paulo.

Due to the occurrence of $H$. axyridis in several locations in Brazil, mainly in the South and Southeast (MARTINS et al., 2009), where there are important areas of fruit production, and records of this species in orchards of fruits (CFC Guedes, personal communication), this study has evaluated its potential in the utilization of different fruit species as food.

\section{MATERIAL AND METHODS}

\section{Insects rearing}

$H$. axyridis adults were collected in pine in September 2008, in Curitiba, PR, and reared in 500$\mathrm{mL}$ plastic containers in an environmental chamber at $25^{\circ} \mathrm{C} \pm 1{ }^{\circ} \mathrm{C}, \mathrm{RH} 70 \% \pm 10 \%$, and photophase of 12 h. Cinara atlantica (Wilson, 1919) (Hemiptera: Aphididae), the giant pine aphid, was provided daily in sufficient quantity to maintain the population stock. Later, adults were sexed based on the methodology of McCornack et al. (2007) and after obtaining the eggs, they were transferred to Petri dishes with moistened filter paper for the experiments. The exchange and cleaning of the containers were made every $48 \mathrm{~h}$, and the observations were made daily. It was used insects of the third generation.

After the eggs hatched, the larvae were isolated in Petri dishes lined with filter paper and a cotton swab moistened with a drop of honey. As food, were offered small aphids to the first instar of $H$. 
axyridis and medium and adults to the other instars. Five to six aphids were offered to the first instar, 12 to 13 to the second instar, 22 to 23 to the third instar, 46 to 47 to the fourth instar, and 22 to 23 aphids to adults (including nymphs and adults). To estimate the number of aphids to be used for feeding, we used the data obtained by Santos (2009). After the pre-pupa to adult emergence, insects were maintained under the same conditions.

\section{Study design}

The design and methods were modified from Koch et al. (2004). The tests were set in the rearing insect laboratory and were conducted at $25^{\circ} \mathrm{C} \pm$ $1{ }^{\circ} \mathrm{C}, \mathrm{RH} 70 \% \pm 10 \%$, and photophase of $12 \mathrm{~h}$. Three different fruits were used: apples, Gala and Fuji; grapes, Niágara and Rubi; and pears, Williams and Asian Pear Ya Li. Ripe fruits were used after they had been obtained from regular cultivars.

For each experiment, 15 repetitions were made. In each repetition, 5 adults two-weeks-old of H. axyridis were used. A total of 75 adults, obtained by rearing were used per experiment. The insects used in the experiments were starved for $6 \mathrm{~h}$ before the beginning of each experiment. At the end of the experiments, it was offered again $C$. atlantica to the beetles. During all the experiments and 2 weeks after the end, observations were made to verify the influence of fruit diet on oviposition.

The counting of the insects on each fruit and the verification of the occurrence of feeding or damage were made during $2 \mathrm{~min}$, after 2, 4, 6, 24, 48 , and $72 \mathrm{~h}$. We considered visiting insects as those found on the fruits at the moment of observation.

\section{Tests with undamaged fruits}

In the grape experiments, a group of 3 Niágara berries was placed into a $500-\mathrm{mL}$ plastic container with punched cover and in the Gala apple and Williams pear tests, 1 unit of each fruit was placed into each $1000-\mathrm{mL}$ plastic container, with $H$. axyridis adults.

\section{Comparison between damaged and undamaged fruits}

The damage in the fruits was also modified from the methodology used by Koch et al. (2004), where each fruit was damaged by punching a 0.75 -cm-diameter hole, $\cong 0.25 \mathrm{~cm}$ in depth.

In the Niágara grape experiments, 2 groups of 3 berries were placed at opposite ends of each one of the containers. One of the groups in each container was damaged with a cut at the posterior tip of each berry, while the other group remained undamaged.
In the Gala apple and Williams pear experiments, the damaged and undamaged fruits were placed at opposites ends of each container. In each one of the damaged apples and pears, 6 cuts in the middle area of the fruits were made, while the others remained undamaged.

\section{Comparison between different fruit cultivars}

In the tests comparing Niágara and Rubi grapes, 1 group of 3 damaged berries of each cultivar was placed at opposites ends of each container. In the Gala and Fuji apples and Williams and Asian pear experiments, 1 damaged unit of each fruit was placed into opposite ends of each container. The fruits were damaged according to the methodology used in the previous item.

\section{Data Analyses}

The data were analyzed using Paleontological Statistics (PAST) program (HAMMER et al., 2001). The mean difference was compared with zero, which indicates no preference. Data were analyzed by the time-period by using a $t$-test on the mean difference between the numbers of $H$. axyridis adults on one choice versus the other choice, all at 5\% level of significance.

\section{RESULTS}

During all the experiments, oviposition was not observed on any of the fruits, probably because of the low quantity of nutrients. At the end of the experiments, beetles were offered the giant pine aphid, C. atlantica, and only after the second week, ovipositions were observed.

\section{Tests with undamaged fruits}

In the undamaged fruit experiments, adult H. axyridis did not cause any perceptive damage to grapes, apples, and pears.

In the Gala apple tests, the death of $2.67 \%$ of the insects at $48 \mathrm{~h}$ and $6.67 \%$ at $72 \mathrm{~h}$ was observed. A similar result was observed for the Williams pears: $5.33 \%$ at $48 \mathrm{~h}$ and $6.67 \%$ at $72 \mathrm{~h}$. For the Niágara grapes, this percentage was higher: $9.33 \%$ at $48 \mathrm{~h}$, and $12 \%$ at $72 \mathrm{~h}$.

\section{Comparison between damaged and undamaged fruits}

In the damaged and undamaged fruit tests, a significantly higher percentage of $H$. axyridis adults were found in damaged fruits compared with the undamaged ones, for all fruit cultivars (Table 1). 
During all periods, in the Gala apple experiment, there was a preference for the damaged fruits, and the quantity of insects present on these fruits increased through time. After a 24-h-period, the insects had moved almost entirely to the damaged fruits. During $72 \mathrm{~h}$ of observation, the number of non-visiting insects was higher than the visitors of undamaged fruits (Table 1). The percentage of insect mortality was low, being $1.33 \%$ at $48 \mathrm{~h}$ and $2.67 \%$ at $72 \mathrm{~h}$.

In the first $2 \mathrm{~h}$ of the Niagara grape experiment, the number of non-visiting individuals was a little higher; however, after $4 \mathrm{~h}$, there was a preference for the damaged fruits, with an increase in the quantity of insects present on these fruits in all periods. The number of visiting insects of the undamaged fruits was very low, mainly after 24 and $72 \mathrm{~h}$, when no $H$. axyridis adults were observed on undamaged fruits (Table 1). As in the Gala apple experiment, insect mortality percentage was low, as the death of $1.33 \%$ of the insects at $6 \mathrm{~h}, 4 \%$ at $48 \mathrm{~h}$, and $2.67 \%$ at $72 \mathrm{~h}$ was verified.

In the Williams pear experiment, during the first $4 \mathrm{~h}$, neither undamaged nor damaged fruits were visited by most insects. In the first $2 \mathrm{~h}$, the number of non-visiting individuals was almost twice the number of visiting individuals of damaged fruits; however, after $6 \mathrm{~h}$, there was a preference for the damaged fruits. Between 48 and $72 \mathrm{~h}, \mathrm{H}$. axyridis adults moved almost entirely to the damaged fruits (Table 1). The mortality rate was also low, as the deaths of $2.67 \%$ of the insects at $48 \mathrm{~h}$ and $4 \%$ at $72 \mathrm{~h}$ were confirmed.

\section{Comparison between different cultivars}

In the different cultivar tests, there was always a significant preference for one cultivar over the other (Table 2).

In the Gala and Fuji apple experiment, during the entire period, there was a preference for Gala. In the first $2 \mathrm{~h}$, the number of non-visiting insects was higher; however, over time, this value decreased and there was an increase in the number of individuals on the Gala cultivar. Mortality was $4 \%$.

In the Niágara and Rubi grape experiments, there was a preference for Niágara during all periods. Only during the first $2 \mathrm{~h}$, there was a greater number of non-visiting insects in relation to the visiting ones in Rubi grapes. The mortality rate was $4 \%$ of the insects at $48 \mathrm{~h}$.

In the Williams and Asian pear experiment, there was a preference for Williams during all periods. The Asian cultivar was little visited during the experiment, being visited by no insect in the 72-h period. There was $100 \%$ survival during the period.

\section{DISCUSSION}

In the undamaged fruits tests, although $H$. axyridis adults did not cause apparent damage, the insects were concentrated close to the stem, probably because this area is less resistant, which facilitates feeding. Similar results were obtained with Magic Lantern pumpkins, Crimson Seedless grapes, and Honeycrisp apples by Koch et al. (2004). However, in tests conducted in 2002 by the same author with undamaged raspberries, $H$. axyridis did cause feeding damage in about $73 \%$ of the replications. In 2003, $70 \%$ and $40 \%$ of the replications for Heritage and Kiwi Gold raspberries, respectively, also had obvious feeding damages, probably because of the fragility of the fruit. According to Galvan et al. (2008), H. axyridis was also not able to damage Frontenac grapes, in laboratory conditions. However, Kovach (2004) showed divergent conclusions, with $H$. axyridis damaging grapes, apples, and peaches; however, only a small number of adults were found feeding on undamaged grapes in the tests.

The choice test feeding with damaged and undamaged fruits showed similar results to those with Honeycrisp apples, Crimson Seedless and Frontenac grapes, and Heritage raspberries by Koch et al. (2004). For all periods, of all fruit cultivars, there were significantly more $H$. axyridis adults on damaged fruits, compared with undamaged. In the study by Kovach (2004) using Gala apples, Red haven peaches, and Red Flame grapes, significantly more adults were observed feeding on damaged fruits. In the field, the proportion of $H$. axyridis was higher in clusters with damaged Leon Millot grapes than with undamaged grapes $(\mathrm{KOCH}$; GALVAN, 2008). Galvan et al. (2007) suggest that many of $H$. axyridis adults arrive in the vineyard 2-3 weeks before the harvest and that the increase in beetle density in clusters depends primarily on the increase in clusters with damaged berries.

In the feeding choice test for different cultivars, Koch et al. (2004) also found significant differences between some of the cultivars. In the apple case, after $2 \mathrm{~h}$, more $H$. axyridis adults were found on Fireside compared to Haralson, but the difference in abundance decreased through time. For raspberry, there was a preference only for the Gold Kiwi cultivar to Heritage after 6 h; however, for grapes there was no preference for any of the cultivars.

The preference for the fruit cultivars can be explained by the concentration of sugars, as tested by Koch et al. (2004) with Fireside and Haralson apples. 
The authors observed that Fireside contained a higher concentration of sugar. The acidity (percentage of malic acid) may also influence the preference. In the same study, the authors mentioned that the percentage of malic acid of Haralson is more than twice as that of Fireside. The rigidity of the fruit skins also seems to be an important aspect in the choice, because the cultivars chosen by insects had less tough skins, which may have facilitated the introduction of the insect mandibles in fruits, as it has also been observed by Koch et al. (2004).

The fruit is a rich source of carbohydrates and may represent a strategy for attaining simple carbohydrates before overwintering (KOCH et al., 2004). In the United States, the ripening conditions of grape berries (e.g., berry injury and sugar content) are also important factors for determining the level of $H$. axyridis infestation in clusters $(\mathrm{KOCH}$; GALVAN, 2008). The largest amount of this species is found at the end of ripening period of fruits, close to the harvest period, when the clusters concentrate the highest quantity of sugars and are more susceptible to damage.

One of the main causes of grape damage would be physiological splitting, an opening in the fruit caused by the sudden increase in absorption and/or adsorption of water, atmospheric humidity, or temperature, and its control, at least partly, depends on the cultural management and water stress of the vines. To prevent these insects from being attracted to damaged fruits, growers can reduce berry injury caused by splitting by selecting varieties with resistance or tolerance to splitting, by using irrigation to avoid long periods of drought, and avoiding injuring berries when pruning or spraying $(\mathrm{KOCH}$; GALVAN, 2008).

Harmonia axyridis presents a great damage potential to the wine industry in the United States and economic consequences of this pest include complete loss of the contaminated wine or increased production costs (KOCH; GALVAN, 2008). Several procedures have been used to try to treat the processed wine contaminated with $H$. axyridis, but none had 100\% efficiency (KOCH; GALVAN, 2008). Therefore, the use of control measures before $H$. axyridis contaminate crops is essential to reduce the economic impact of this insect in the wine industry (GALVAN et al., 2009).

TABLE 1- Mean number of adut Harmonia axyridis (Pallas, 1773) on damaged and undamaged fruits in a laboratory choice test $\left(25^{\circ} \mathrm{C}, 12 \mathrm{~h}\right.$ photophase and $\left.\mathrm{RH} 70 \pm 10 \%\right)$.

\begin{tabular}{cccccccc}
\hline Cultivar & Time & Damaged & Undamaged & Non-visiting & $\mathrm{t}$ & $\mathrm{df}$ & $\mathrm{P}$ \\
\hline Gala & 2 & $2,27 \pm 0,80$ & $0,80 \pm 0,68$ & $1,93 \pm 1,16$ & 7,16 & 14 & $<0,001$ \\
& 4 & $2,93 \pm 0,80$ & $0,93 \pm 0,80$ & $1,13 \pm 0,74$ & 9,14 & 14 & $<0,001$ \\
& 6 & $3,33 \pm 0,72$ & $0,53 \pm 0,64$ & $1,13 \pm 0,94$ & 12,73 & 14 & $<0,001$ \\
& 24 & $3,80 \pm 0,94$ & $0,27 \pm 0,46$ & $0,93 \pm 0,80$ & 13,57 & 14 & $<0,001$ \\
& 48 & $3,13 \pm 0,99$ & $0,27 \pm 0,46$ & $0,53 \pm 0,83$ & 13,03 & 14 & $<0,001$ \\
& 72 & $3,87 \pm 1,08$ & $0,20 \pm 0,41$ & $0,80 \pm 0,77$ & 12,28 & 14 & $<0,001$ \\
\hline Niágara & 2 & $2,27 \pm 0,88$ & $0,33 \pm 0,62$ & $2,4 \pm 1,06$ & 7 & 14 & $<0,001$ \\
\hline & 4 & $3,07 \pm 1,16$ & $0,40 \pm 0,74$ & $1,53 \pm 1,13$ & 6,59 & 14 & $<0,001$ \\
& 6 & $3,27 \pm 1,39$ & $0,20 \pm 0,41$ & $1,47 \pm 1,46$ & 8,2 & 14 & $<0,001$ \\
& 24 & $3,63 \pm 1,22$ & 0 & $1,00 \pm 1,25$ & $*$ & $*$ & $*$ \\
& 48 & $3,80 \pm 0,77$ & $0,13 \pm 0,35$ & $0,80 \pm 0,94$ & 16,86 & 14 & $<0,001$ \\
& 72 & $3,97 \pm 0,74$ & 0 & $0,73 \pm 0,80$ & $*$ & $*$ & $*$ \\
\hline Willians & 2 & $1,60 \pm 0,91$ & $0,40 \pm 0,63$ & $3,00 \pm 1,13$ & 4,19 & 14 & $<0,001$ \\
\hline & 4 & $2,13 \pm 0,74$ & $0,47 \pm 0,74$ & $2,40 \pm 1,18$ & 6,13 & 14 & $<0,001$ \\
& 6 & $2,80 \pm 0,56$ & $0,53 \pm 0,74$ & $1,67 \pm 1,11$ & 9,53 & 14 & $<0,001$ \\
& 24 & $3,20 \pm 1,74$ & $0,47 \pm 0,83$ & $1,33 \pm 1,72$ & 5,48 & 14 & $<0,001$ \\
& 48 & $4,13 \pm 0,64$ & $0,27 \pm 0,59$ & $0,60 \pm 0,52$ & 17,14 & 14 & $<0,001$ \\
& 72 & $4,07 \pm 0,70$ & $0,13 \pm 0,52$ & $0,80 \pm 0,74$ & 17,5 & 14 & $<0,001$ \\
\hline
\end{tabular}

The t-test compares damaged versus undamaged fruits. 
TABLE 2 - Mean number of adult Harmonia axyridis (Pallas, 1773) on different damaged fruit cultivars in a laboratory choice test $\left(25^{\circ} \mathrm{C}, 12 \mathrm{~h}\right.$ photophase and $\left.\mathrm{RH} 70 \pm 10 \%\right)$.

\begin{tabular}{cccccccc}
\hline Choices & Time & Gala & Fuji & Non- visiting & t & DF & P \\
\hline Apple: Gala X Fuji & 2 & $2,33 \pm 0.98$ & $0,8 \pm 0,86$ & $1,87 \pm 1,25$ & 4,51 & 14 & $<0,001$ \\
\hline & 4 & $2,47 \pm 0,64$ & $1,2 \pm 0,77$ & $1,33 \pm 0,98$ & 4,92 & 14 & $<0,001$ \\
& 6 & $2,6 \pm 0,91$ & $1,2 \pm 0,94$ & $1,2 \pm 1,01$ & 4,17 & 14 & $<0,001$ \\
& 24 & $2,93 \pm 0,8$ & $0,93 \pm 0,88$ & $1,13 \pm 1,06$ & 6,52 & 14 & $<0,001$ \\
& 48 & $3,27 \pm 0,88$ & $0,93 \pm 0,46$ & $0,8 \pm 0,86$ & 9,15 & 14 & $<0,001$ \\
& 72 & $3,47 \pm 0,99$ & $0,8 \pm 0,86$ & $0,73 \pm 0,64$ & 7,88 & 14 & $<0,001$ \\
\hline & Time & Niágara & Rubi & Non- visiting & t & DF & P \\
\hline Grape: Niágara X Rubi & 2 & $2,4 \pm 1,12$ & $0,93 \pm 0,8$ & $1,67 \pm 1,59$ & 4,14 & 14 & $<0,001$ \\
\hline & 4 & $3,07 \pm 0,7$ & $1,27 \pm 0,56$ & $0,67 \pm 0,8$ & 7,77 & 14 & $<0,001$ \\
& 6 & $3,67 \pm 1,05$ & $0,73 \pm 0,88$ & $0,6 \pm 0,51$ & 8,33 & 14 & $<0,001$ \\
& 24 & $3,4 \pm 0,8$ & $1 \pm 0.96$ & $0,6 \pm 0,86$ & 7,44 & 14 & $<0,001$ \\
& 48 & $3,53 \pm 1,13$ & $0,87 \pm 1,01$ & $0,6 \pm 0,52$ & 6,79 & 14 & $<0,001$ \\
& 72 & $3,8 \pm 0,68$ & $0,67 \pm 0,49$ & $0,53 \pm 0,49$ & 14.49 & 14 & $<0,001$ \\
\hline Time & Williams & Asiática & Non- visiting & t & DF & P \\
\hline Pear: Williams XAsiática & 2 & $2,33 \pm 1,29$ & $0,53 \pm 0,74$ & $2,13 \pm 1,64$ & 4,69 & 14 & $<0,001$ \\
\hline & 4 & $2,67 \pm 0,82$ & $0,87 \pm 0,92$ & $1,47 \pm 0,92$ & 5,67 & 14 & $<0,001$ \\
& 6 & $3,33 \pm 0,62$ & $0,73 \pm 0,8$ & $0,93 \pm 1,03$ & 9,97 & 14 & $<0,001$ \\
& 24 & $3,2 \pm 1,74$ & $0,47 \pm 0,83$ & $1,33 \pm 1,72$ & 5,49 & 14 & $<0,001$ \\
& 48 & $4,27 \pm 0,7$ & $0,27 \pm 0,59$ & $0,47 \pm 0,52$ & 16,9 & 14 & $<0,001$ \\
& 72 & $4,27 \pm 0,7$ & 0 & $0,73 \pm 0,7$ & $*$ & $*$ & $*$ \\
\hline
\end{tabular}

The t-test compares one variety of damaged fruit versus another.

\section{CONCLUSION}

Under the studied conditions, $H$. axyridis does not seem to present potential as a fruit pest in Brazil; however, it is likely to cause problems in the field, if large populations occur, causing injury and making way for the damage, because when prey is scarce, they search for other sources of food. In the case of grapes, the most susceptible fruit in our study, as infestations appear to be dependent on damaged fruits, what is also shown in our study, producers should prevent and minimize damages caused by other agents such as birds, wasps, and caterpillars, which can attract $H$. axyridis.

\section{ACKNOWLEDGMENTS}

We would like to thank Dr. Mauricio Osvaldo Moura for helping with the statistical analysis and Danielle Marilia Gabaldi Andre, who helped with the English editing of the manuscript. To CAPES scholarship to the first author and CNPq fellowship LMA (306772/2006-0).

\section{REFERENCES}

ALMEIDA, L.M.; SILVA, V.B. Primeiro registro de Harmonia axyridis (Pallas) (Coleoptera, Coccinellidae): um coccinelídeo originário da região Paleártica. Revista Brasileira de Zoologia, Curitiba, v.19, p.941-944, 2002.

COLUNGA-GARCIA, M.; CAGE, S.H. Arrival, establishment, and habitat use of the multicolored Asian lady beetle (Coleoptera: Coccinellidae) in a Michigan landscape. Environmental Entomology, College Park, v.27, p.1574-1580, 1998.

GALVAN, T.L.; BURKNESS, B.L.; KOCH, R.L.; HUTCHISON, W.D. Multicolored Asian Lady Beetle (Coleoptera: Coccinellidae) Activity and Wine Grape Phenology: Implications for Pest Management. Environmental Entomology, College Park, v.38, n.6, p.1563-1574, 2009.

GALVAN, T.L.; BURKNESS, E.C.; VICKERS, Z.; STENBERG, P.; MANSFIELD, A.K.; HUTCHISON, W.D. Sensory-based action threshold for multicolored Asian lady beetlerelated-taint in winegrapes. American Journal of Enology and Viticulture, Davis, v.58, n.4, p.518-522, 2007. 
GALVAN, T.L.; KOCH, R.L.; HUTCHISON, W.D. Impact of fruit feeding on overwintering survival of the multicolored Asian lady beetle, and the ability of this insect and paper wasps to injure wine grape berries. Entomologia Experimentalis et Applicata, Dordrecht, v.128, p.429-436, 2008.

HAMMER, O.; HARPER, D.A.T.; RYAN, P.D. PAST: Paleontological statistics software package for education and data analysis. Palaeontologia Electronica, Lawrence, v.4, n.1, p.9, 2001.

HODEK, I.; EMDEN, V.H.F.; HONEK, A. Ecology and Behaviour of the Ladybird Beetles (Coccinellidae). New Jersey: Wiley-Blackwell Publishing, 2012. $604 \mathrm{p}$.

KOCH, R.L. The Multicolored Asian Lady beetle, Harmonia axyridis: A review of its biology, uses in biological control and non-target impacts. Journal of Insect Science, Wellingford, v.32, p. 1-16, 2003.

KOCH, R.L.; BURKNESS, E.C.; BURKNESS, S.J.W.; HUTCHISON, W.D. Phytophagous Preferences of the Multicolores Asian Lady Beetle (Coleoptera: Coccinellidae) for Autumn-Ripering Fruit. Journal of Economic Entomology, Lanham, v.97, n.2, p.539-543, 2004.

KOCH, R.L.; GALVAN, T.L. Bad side of a good beetle: the North American experience with Harmonia axyridis. BioControl, Dordrecht, v.53, p.23-35, 2008.

KOVACH, J. Impact of Multicolored Asian Lady Beetles as a Pest of Fruit and People. American Entomologist, Lanham, v.50, p.159-161, 2004.
LAMANA, M.L.; MILLER, J.C. Field observations on Harmonia axyridis Pallas (Coleoptera: Coccinellidae) in Oregon. Biological Control, Orlando, v.27, n.4, p.1001-1005, 1998.

MARTINS, C.B.C.; ALMEIDA, L.M.; ZONTADE-CARVALHO, R.C.; CASTRO, C.F.; PEREIRA, R.A. Harmonia axyridis: a threat to Brazilian Coccinellidae? Revista Brasileira de Entomologia, São Paulo, v.53, n.4, p.663-671, 2009.

McCORNACK, B.P.; KOCH, R.L.; RAGSDALE, D.W. A simple method for in-field sex determination of the multicolored Asian lady beetle Harmonia axyridis. Journal of Insect Science, Walingford, v.7, p.1-12, 2007.

MIGNAULT, M.P.; ROY, M.; BRODEUR, J. Soybean aphid predators in Quebec and the suitability of Aphis glycines as prey for three Coccinellidae. Biological Control, Orlando, v.51, p.89-106, 2006.

SANTOS, A.A. Aspectos biológicos e capacidade de consumo de Harmonia axyridis (Pallas, 1773) (Coleoptera, Coccinellidae). 2009. Dissertação (Mestrado) - Universidade Federal do Paraná, Curitiba, 2009.

TEDDERS, W.L.; SCHAEFER, P.W. Release and establishment of Harmonia axyridis in the southeastern United States. Entomological News, Philadelphia, v.105, p.228-243, 1994. 